\title{
Meio ambiente e cidadania: uma perspectiva sobre o desenvolvimento sustentável
}

\author{
Arismar Maneia', Wagner Carmo², Aloisio Krohling ${ }^{3}$ \\ ${ }^{2}$ Departamento de Mestrado em Tecnologia Ambiental, Faculdades Integradas de Aracruz, Espírito Santo \\ ${ }^{3}$ Faculdades Integradas de Aracruz, Espírito Santo
}

\section{Resumo}

Este artigo tem como objetivo mostrar, a partir do art. 225 da Constituição Federal de 1988, a responsabilidade dos cidadãos no processo de planejamento, discussão e execução de políticas ambientais. O ponto de partida, aqui, é compreender os termos meio ambiente e cidadania. O foco está no art. 225 da Constituição Federal brasileira, que atribui ao Estado e à Coletividade o dever de preservar o meio ambiente, e no fato de que, em regra, o cidadão exime-se de sua obrigação, atribuindo toda a responsabilidade apenas ao Estado. A proposta, então, é desenvolver reflexões que incluem conceitos, o papel da sociedade e do cidadão e a indicação de ferramentas que possibilitem o efetivo desenvolvimento econômico sustentável com pleno envolvimento e participação do Estado, das pessoas jurídicas e das pessoas naturais. O estudo concluiu que o homem necessita com urgência repensar os valores morais e suas ações diante do mundo, deixando de ser mero receptor para ser fomentador de direito.

Palavras-chave: Constituição Federal de 1988. Meio ambiente. Cidadania.

\begin{abstract}
This article aims to show, from the art. 225 of the Federal Constitution of 1988, the responsibility of citizens in the process of planning, discussion and implementation of environmental policies. The starting point, here, is understand the words environment and citizenship. The focus is on art. 225 of the Brazilian Federal Constitution, which assigns to the State and the collective duty to preserve the environment, and the fact that, as a rule, the citizen declines of their obligation by assigning all responsibility only to the State. The proposal then is to develop ideas which include concepts, the role of society and the citizen and an indication of the effective tools which enable sustainable economic development with full involvement and participation of the State, legal persons and natural persons. The study concluded that the man needs to urgently rethink the moral values and its actions before the world, no longer mere receiver to be developer of right
\end{abstract}

Keywords: . He Federal Constitution of 1988. Environment. Citizenship. 


\section{INTRODUÇÃO}

É fácil perceber através dos noticiários de TV, jornais e revistas que o meio ambiente no Brasil e no mundo é um dos focos principais das discussões. A humanidade precisa despertar para a dura realidade que ela mesma construiu e que hoje a coloca à mercê da própria sorte e em ameaça de extinção.

Para Beck (1997), devemos reconsiderar a essência da crise ecológica como uma das varias metamorfoses dos efeitos colaterais despercebidos da produção industrial em perspectivas globais. Trata-se não somente de um chamado aos problemas ambientais, mas sim uma crise institucional profunda da própria sociedade industrial.

Por isso, Meio Ambiente e Cidadania: uma perspectiva sobre o desenvolvimento sustentável pretende apurar, a partir do art. 225 da Constituição Federal de 1988, a responsabilidade dos cidadãos no processo de planejamento, discussão e execução de políticas ambientais.

Parte-se, inicialmente, da compreensão dos termos meio ambiente e cidadania,os quais, estudados na Academia, representam, atualmente, a vedete popular do jargão político. Muito se fala em preservação do meio ambiente ou em resgate da cidadania, mas,sem a compreensão exata da dimensão do que seja meio ambiente e do que seja cidadania, não é possível evitara ocorrência de um processo dicotômico em relação ao desenvolvimento econômico sustentável e às ações humanas no meio ambiente.

De acordo com a Constituição Federal brasileira, em seu art. 225, a preservação do meio ambiente é dever do Estado e da Coletividade. Contudo, em regra, o cidadão exime-se de sua obrigação, imputando toda a responsabilidade apenas ao Estado.

Destaca-se, ainda, o fato de muitos acreditarem que o desenvolvimento sustentável e a garantia do meio ambiente equilibrado se realizam com a mera participação dos cidadãos em audiências públicas, conselhos e organizações não governamentais.

Seria, então, possível crescer, desenvolver-se e preservar o meio ambiente sem a participação do cidadão? Quais seriam as ações que exigem a participação do Estado e do Cidadão para o desenvolvimento econômico sustentável e a preservação do Meio Ambiente? A compreensão de meio ambiente não inclui a ação do individuo de forma propositiva? O estabelecimento de mecanismos participativos, tais como as audiências públicas, atendem plenamente a ideia de cidadania em matéria ambiental?

Soma-se a tudo isso o resultado da ação inversa do cidadão em relação ao meio ambiente. A inflexão está no fato de que o consumo é uma ameaça à condição de sobrevivência da humanidade. Em outras palavras, o cidadão, além de não compreender o seu papel no desenvolvimento sustentável, acaba realizando ações negativas por meio de uma proposta de desenvolvimento pautada pelo consumo desorganizado, oriundo do fenômeno da globalização - responsável por afetar o modo de vida de toda a população mundial.

O relatório do desenvolvimento humano (PNUD, 1998, p. 38), citado por Feldmann (2003, p. 148), indica que a sociedade mundial encontra-se distante de realizar um consumo que seja sustentável. Vejamos a definição:

O consumo contribui claramente para o desenvolvimento humano, quando aumenta suas capacidades, sem afetar adversamente o bem-estar coletivo quando é tão favorável para as gerações futuras como para as presentes, quando respeita a capacidade de suporte do planeta e quando encoraja a emergência de comunidades dinâmicas e criativas.

A ideia, portanto, é desenvolver reflexões que perpassam pelos conceitos, discutir o papel da sociedade e do cidadão e alcançar a indicação de ferramentas que possibilitem o efetivo desenvolvimento econômico sustentável com pleno envolvimento e participação do Estado, das pessoas jurídicas e das pessoas naturais.

\section{O MEIO AMBIENTE E A CIDADANIA}

\section{I CONCEITOS}

\section{I.I Aproximações do conceito de cidadania}

Diferentemente dos anos 60 e 70, o tema cidadania, atualmente, não possui conotação pejorativa de espécie de engodo norte-americano, destacado para realizar dialética entre o capitalismo e o 
socialismo real (COVRE, 1991 apud NEVES et al., 2007).A cidadania no Ocidente evoluiu e tornou-se referencial de sustentação para a pauta de diversos movimentos sociais que reivindicam saneamento básico, saúde, educação, fim da discriminação racial e sexual etc.

No Brasil, com o advento da Carta de 1988 e o fortalecimento da democracia e das Instituições, uma série de direitos sociais foi criada sem, contudo, estarem assegurados materialmente quanto à execução e alcance da população de menor potencial econômico. O fato é que houve uma verdadeira explosão de direito, porém, em razão das desigualdades sociais, observa-se que alguns passaram a acessar toda sorte de bens econômicos e direitos; outros nada ou quase nada sejam pela baixa renda ou pela falta de expressão.

Logo, para discutir cidadania nesse ambiente é fundamental compreender que o que é cidadania para um grupo social não é, necessariamente, cidadania para outro grupo social. Percebe-se, portanto, que para conceituar e exercer a cidadania não basta, e não é suficiente, o estabelecimento de direitos. Não basta, ainda, apenas elevar políticas sociais à categoria de direitos.

O que é cidadania? Em uma primeira aproximação é ser cidadão com direito de votar. Contudo quem já teve alguma experiência política - na igreja, no bairro, no sindicato, na escola etc. - sabe que o ato de votar não garante nenhuma cidadania, se não vier acompanhado de determinadas condições de nível econômico, político, social e cultural.

Outra aproximação do conceito de cidadania, mais aceitável, indica que ser cidadão significa ter direitos e deveres, ser súdito e ser soberano. Tal conceito defluiu de cartas políticas e jurídicas essenciais à historia da humanidade, quais sejam, a Carta de Direitos da Organização das Nações Unidas (ONU), de 1948, que, por sua vez, possui como matrizes marcantes a Carta de Direitos dos Estados Unidos (1776) e da Revolução Francesa (1798).

A ideia de cidadania como direito passa, primariamente, pelo fato de que todos os homens são iguais, ainda que perante a Lei, sem qualquer tipo de discriminação. Ademais, através de tal conceito, a todos os homens cabe o domínio sobre seu corpo, sua vida, o acesso a um trabalho com salário digno capaz de prover sua vida, o direito à educação, à saúde, à habitação, ao lazer. E mais, é direito de todos poderem expressar-se livremente, militar em partidos políticos e sindicatos, fomentar movimentos sociais, lutar por seus valores.

Contudo o conceito de cidadania não encerra apenas direito, pois implica reconhecer a existência de deveres. A cidadania deve levar o cidadão a ser o próprio fomentador da existência dos direitos a todos, ter responsabilidade em conjunto pela coletividade, cumprir normas e propostas elaboradas e decididas coletivamente, fazer parte do governo - direta ou indiretamente, ao votar, ao pressionar através dos movimentos sociais, ao participar de assembleias - no bairro, no sindicato, na escola. E, ainda, pressionar os governos municipais, estaduais e federais, além de organismos internacionais, como o FMI.

Vê-se que o conteúdo de cidadania apenas é possível pela prática da reivindicação, da apropriação de espaços, da pugna para fazer valer os direitos do cidadão. Neste sentido, a prática da cidadania pode ser a estratégia por excelência para construção de uma sociedade melhor. Assim, um primeiro passo para alcançar o conteúdo de cidadania é espargir os direitos dos cidadãos de forma a garantir que toda a população conheça seus direitos e seus deveres.

A principal questão é a mudança de paradigma. No modelo atual as pessoas tendem a pensar cidadania apenas em termo de direitos a receber, negligenciando o fato de que elas próprias podem ser agentes da existência desses direitos.Em regra, no exercício de sua cidadania o cidadão espera apenas receber direitos, atuando como mero receptor, deixando de ser protagonista da luta pelo direito.

A perspectiva ideal recomenda que o cidadão atue propositivamente sempre que estiver diante de um problema. O conteúdo de cidadania exige, por exemplo, que diante de um problema no bairro ou na rua o cidadão não espere a solução espontaneamente. Nestes casos, o melhor seria que os moradores se organizassem e buscassem as soluções.

Um exemplo cotidiano, no Brasil, é o mau gerenciamento do lixo.Trata-se de uma realidade e um dos fatores causadores de sérios impactos ambientais, além de contribuir para a geração de doenças, colocando em risco a saúde pública. O lixo no Brasil ainda é visto como algo desprezível e sem a menor importância, tendo em vista o risco que pode causar. A sociedade brasileira, em geral, não enxerga o lixo como responsabilidade de cada um, atribuindo-se ao poder público toda a responsabilidade pelo destino do lixo produzido no país.

Para Covre (1991), cidadania é o próprio direito à vida no sentido pleno. Trata-se de um direito 
que precisa ser construído coletivamente, não só em termos do atendimento às necessidades básicas, mas de acesso a todos os níveis de existência, incluindo o mais abrangente, o papel do(s) homem (ns) no Universo.

A compreensão do conteúdo de cidadania deve passar essencialmente pela análise de três direitos: direito civil, direito político e direito social. Contudo a separação em direitos não ilide a compreensão do todo,pois se trata de direitos que compõem os direitos do cidadão e não podem ser vistos isoladamente (COVRE, 1991).

A autora afirma que os direitos civis dizem respeito basicamente ao direito de se dispor do próprio corpo, locomoção, segurança.Já os direitos políticos dizem respeito à deliberação do homem sobre sua vida, ao direito de ter livre expressão de pensamento e prática política, religiosa, relacionar conviver com outros homens em organismos sociais governamentais e não governamentais. Por fim, os direitos sociais dizem respeito ao atendimento das necessidades humanas básicas. São direito sociais: alimentação, habitação, saúde, educação, meio ambienta equilibrado, trabalho, salário etc.

\subsubsection{Aproximações do conceito de meio ambiente}

A expressão meio ambiente (milieu ambiance) foi utilizada pela primeira vez pelo naturalista francês Geoffrey de Saint-Hilaire, em sua obra Études progressives d'un naturaliste, de 1835, na qualmilieu significa o lugar onde está ou se movimenta um ser vivo, e ambiance designa o que rodeia esse ser.

Há uma grande discussão em torno da redundância do termo meio ambiente, por conter duas palavras com significados similares, como observa Vladimir Passos de Freitas (2001, p. 17):

A expressão meio ambiente, adotada no Brasil, é criticada pelos estudiosos, porque meio e ambiente, no sentido enfocado, significam a mesma coisa. Logo, tal emprego importaria em redundância. Na Itália e em Portugal usa-se, apenas, a palavra ambiente.

Gastão Octávio da Luz (2001), doutor em meio ambiente e desenvolvimento, analisando dicionários e enciclopédias de várias épocas, constata que o material fornecido pelos autores tende a promover a sinonímia entre meio e ambiente. Dessa forma, enquanto conceitos, os verbetes perdem seu valor objetivo e, quanto à representação conceitual, poderiam ser ditos como sendo confusos e obscuros.

Conforme Aceti Júnior (2007), o Novo Dicionário da Língua Portuguesa Aurélio define meio como lugar onde se vive, com suas características e condicionamentos geofísicos, ambiente, esfera social ou profissional onde se vive ou trabalha, e ambiente como o conjunto de condições naturais e de influências que atuam sobre os organismos vivos e os seres humanos.

Por outro lado, os defensores do termo afirmam que esta questão não passa de um problema de semântica. Também existe uma forte tendência na manutenção do vocábulo, pois o termo já é popularmente difundido como sendo a designação para os assuntos da natureza, e também que vários organismos internacionais, nacionais, estaduais e municipais já incorporaram o termo às suas siglas, como é o caso do PNUMA (Programa das Nações Unidas para o Meio Ambiente), Ministérios de Meio Ambiente e Secretarias de Meio Ambiente.

No mesmo sentido é o entendimento do mestre ambientalista Edis Milaré (2001, p. 63):

Tanto a palavra meio quanto o vocábulo ambiente passam por conotações, quer na linguagem científica quer na vulgar. Nenhum destes termos é unívoco (detentor de um significado único), mas ambos são equívocos (mesma palavra com significados diferentes). Meio pode significar: aritmeticamente, a metade de um inteiro; um dado contexto físico ou social; um recurso ou insumo para se alcançar ou produzir algo. Já ambiente pode representar um espaço geográfico ou social, físico ou psicológico, natural ou artificial. Não chega, pois, a ser redundante a expressão meio ambiente, embora no sentido vulgar a palavra identifique o lugar, o sítio, o recinto, o espaço que envolve os seres vivos e as coisas. De qualquer forma, trata-se de expressão consagrada na língua portuguesa, pacificamente usada pela doutrina, lei e jurisprudência de nosso país, que, amiúde, falam em meio ambiente, em vez de ambiente apenas.

Lato sensu, meio ambiente é o conjunto de fatores exteriores que agem de forma permanente sobre os seres vivos, aos quais os organismos devem se adaptar e com os quais têm de interagir para sobreviver. Sob o ponto de vista etimológico, pode-se propor compreender o conteúdo de meio ambiente 
[...] comumente chamado apenas de ambiente, envolve todas as coisas vivas e não-vivas ocorrendo na Terra, ou em alguma região dela, que afetam os ecossistemas e a vida dos humanos. È o conjunto de condições, leis, influências e infraestrutura de ordem física, química e biológica, que permite, abrigam e regem a vida em todas as suas formas ${ }^{1}$.

Dissecando o conceito de meio ambiente, é possivel identificá-lo pelos seguintes componentes: a) Completo conjunto de unidades ecológicas que funcionam como um sistema natural sem uma massiva intervenção humana, incluindo toda a vegetação, animais, microrganismos, solo, rochas, atmosfera e fenômenos naturais que podem ocorrer em seus limites; b) Recursos e fenômenos físicos universais que não possuem um limite claro, como ar, água, e clima, assim como energia, radiação, descarga elétrica e magnetismo, que não se originam de atividades humanas.

No âmbito jurídico é difícil definir meio ambiente, pois, como bem lembra Milaré (2003, p. 165), "o meio ambiente pertence a uma daquelas categorias cujo conteúdo é mais facilmente intuído que definível, em virtude da riqueza e complexidade do que encerra".

No Brasil, o conceito legal de meio ambiente encontra-se disposto no art. $3^{\circ}$, I, da Lei $n^{\circ}$ 6.938/81, que dispõe sobre a Política Nacional do Meio Ambiente, que diz que meio ambiente é "o conjunto de condições, leis, influências e interações de ordem física, química e biológica, que permite, abriga e rege a vida em todas as suas formas".

Trata-se de um conceito restrito ao meio ambiente natural, sendo inadequado, pois não abrange de maneira ampla todos os bens jurídicos protegidos. Conforme a lição de José Afonso da Silva, o conceito de meio ambiente deve ser globalizante e

abrangente de toda a natureza, o artificial e original, bem como os bens culturais correlatos, compreendendo, portanto, o solo, a água, o ar, a flora, as belezas naturais, o patrimônio histórico, artístico, turístico, paisagístico e arquitetônico (2004, p. 20).

Dessa forma, o conceito de meio ambiente compreende três aspectos, quais sejam: Meio ambiente natural, ou físico, constituído pelo solo, a água, o ar atmosférico, a flora, enfim, pela interação dos seres vivos e seu meio, onde se dá a correlação recíproca entre as espécies e as relações destas com o ambiente físico que ocupam; Meio ambiente artificial, constituído pelo espaço urbano construído; e Meio ambiente cultural, integrado pelo patrimônio histórico, artístico, arqueológico, paisagístico, turístico, que, embora artificial, difere do anterior pelo sentido de valor especial que adquiriu ou de que se impregnou (SILVA, 2004, p. 21).

Temos, ainda, o Meio ambiente do trabalho, previsto no art. 200, VIII, da Constituição Federal de 1988, ou seja, "o conjunto de fatores físicos, climáticos ou qualquer outro que interligados, ou não, estão presentes e envolvem o local de trabalho da pessoa" (SANTOS, 2001).

Tal conceito de meio ambiente foi recepcionado pela Constituição Federal de 1988, que, em seu art. 225, buscou tutelar não só o meio ambiente natural, mas também o artificial, o cultural e o do trabalho.

Com isso, conclui-se que a definição de meio ambiente apresenta-se complexa e ampla. Sob o ponto de vista legal, observa-se, ainda, que o legislador optou por trazer um conceito jurídico aberto.

Entretanto, para atendimento das particularidades deste trabalho, o conceito não é o elemento mais importante. O essencial é compreender que o homem é parte do meio ambiente e que suas ações ou omissões podem representar impactos positivos ou negativos para a vida no planeta Terra e no Universo.

\section{ATUAÇÃO DO ESTADO E DO CIDADÃO NA DEFESA DO MEIO AMBIENTE}

\section{I O aRTigo 225 da Constituição Federal de 1988}

A Constituição Federal de 1988 foi a primeira em nosso país a abordar diretamente o tema meio ambiente. As constituições anteriores tratavam o tema de forma indireta e com submissão a leis infraconstitucionais.

1 http://site.sabesp.com.br/site/interna/Default.aspx?secaold=112. Acessado em 16 out. 2013. 
A partir desta Carta Magna o meio ambiente passou a ser tido como um bem tutelado juridicamente. Como oportunamente coloca José Afonso da Silva, "a Constituição de 1988 foi, portanto, a primeira a tratar deliberadamente da questão ambiental, trazendo mecanismos para sua proteção e controle, sendo tratada por alguns como "Constituição Verde"” (2004, p. 46).

A matéria é tratada em diversos títulos e capítulos. O Título VIII (Da Ordem Social), em seu Capítulo VI, no art. 225, caput, diz que

Todos têm direito ao meio ambiente ecologicamente equilibrado, bem de uso comum do povo e essencial à sadia qualidade de vida, impondo-se ao Poder Público e à coletividade o dever de defendê-lo e preservá-lo para as presentes e futuras gerações (grifo nosso).

Dessa forma, o Direito Constitucional brasileiro criou uma nova categoria de bem: o bem ambiental, portanto, um bem de uso comum do povo, e, ainda, um bem essencial à sadia qualidade de vida.

Maria Sylvia Zanella Di Pietro (2003, p. 545) leciona que "consideram-se bens de uso comum do povo aqueles que, por determinação legal ou por sua própria natureza, podem ser utilizados por todos em igualdade de condições". Ou seja, são aqueles de que o povo se utiliza, sem restrição, gratuita ou onerosamente, sem necessidade de permissão especial. "Não cabe, portanto, exclusivamente a uma pessoa ou grupo, tampouco se atribui a quem quer que seja sua titularidade" (FIORILLO, 2007, p. 67).

Assim, sob o mote da cidadania, nenhum de nós tem o direito de causar danos ao meio ambiente, pois estaríamos agredindo a um bem de todos, causando, portanto, danos não só a nós mesmos, mas aos nossos semelhantes.

\subsection{A RESPONSABILIDADE DO CIDADÃO E OS INSTRUMENTOS DE CIDADANIA E PRESERVAÇÃO DO MEIO AMBIENTE}

Aproximando as definições de cidadania e de meio ambiente, passa-se a discutir o relacionamento do homem-cidadão com o meio ambiente. Em regra, como já afirmado, o homem relaciona-se sempre a partir da ideia de receptor de direito, deixando de lado duas premissas essenciais: a) que é sujeito de deveres, e b) que deve ser protagonista dos próprios direitos.

Em regra, o que se observa em matéria ambiental não é diferente. O homem relaciona-se com os elementos do meio ambiente de forma antropocêntrica, considerando-se como fonte de todo valor - acima ou fora da natureza. Assim, atribui para o meio ambiente um valor apenas instrumental ou utilitário. O homem, neste particular, apropria-se e utiliza-se dos recursos do meio ambiente como receptor de um direito absoluto e sem fomentar qualquer contrapartida.

Em verdade, o ideal é não separar o homem do ambiente,pois no ambiente nada se separa. Uma visão correta do homem sobre o meio ambiente obriga reconhecer o valor intrínseco de todos os seres vivos e encara o homem como apenas um dos filamentos da teia da vida. A cidadania no meio ambiente determina reconhecer que estamos todos inseridos no mesmo processo cíclico da natureza e que dele dependemos para viver.

$\mathrm{O}$ arcabouço que envolve o tema da cidadania e do meio ambiente circunscreve manter a humanidade crescendo e consumindo através de um desenvolvimento sustentável. E pensar em desenvolvimento sustentável implica lembrar que a preservação do meio ambiente também é responsabilidade do cidadão, e não apenas dos governos e das empresas.

Assim, é necessário alcançar uma definição operacional de meio ambiente e sustentabilidade. Em tese, a chave para alcançar esta definição está em reconhecer a necessidade imperiosa de construir, a partir da sociedade em que vivemos, comunidades sustentáveis. No caso, não precisamos partir do marco zero, bastando moldar a sociedade a partir de novos valores para estilos de vida, negócios, atividades econômicas, estruturas fisicas e tecnológicas, que não interfiram na capacidade da natureza de manter a vida.

Capra (2003) indica que a construção de uma sociedade sustentável deve começar pela alfabetização ecológica, mas o fato é que tanto a alfabetização ecológica quanto a mudança de valores e paradigmas de relacionamento do homem com o ambiente apenas serão possíveis se o homem compreender que ser cidadão ambiental significa muito mais que utilizar o ambiente de forma utilitária. 


\section{CONCLUSÃO}

A humanidade precisa acordar para a dura realidade que ela mesma construiu e que hoje nos põe a mercê da própria sorte e nos ameaça da extinção. $O$ fato real e inevitável que nenhum cidadão pode desconhecer ou evitar é que a humanidade encontra-se sitiada em um pequeno barco sobre um imenso oceano e que, olhando para todas as coordenadas geográficas, não existe nada além do próprio barco para manter a vida.

Estabelecer uma nova compreensão sobre cidadania é crível para alcançar padrões de desenvolvimento e consumo sustentáveis. O homem necessita urgentemente repensar os valores morais e suas ações diante do mundo, deixando de ser mero receptor para ser fomentador de direito. Deve compreender com urgência que possui deveres para com o ambiente em que vive. Estando no barco e sendo o barco o único meio de viver, o homem deve optar por manter o barco flutuando ou afundá-lo, afundando a humanidade.

\section{REFERÊNCIAS}

ACETI JÚNIOR, Luiz Carlos. O Brasil precisa de um Instituto de Direito Ambiental: < ambiente.org.br/Opiniao.asp?artigo=62>. Acessado em: 18set. 2013.

BECK, Ulrich. Modernização reflexiva: política, tradição e estética na ordem social moderna/Ulrich Beck, Anthony Giddens, Scott Lash.Tradução de Magda Lopes. São Paulo: Editora da Universidade Estadual Paulista, 1997.

BRASIL. Lei $\mathbf{N}^{\mathbf{0}}$ 6.938, de 31 de agosto de 1981. Dispõe sobre a Política Nacional do Meio Ambiente, seus fins e mecanismos de formulação e aplicação, e dá outras providências.

CAPRA, Fritjof. Meio ambiente no século 21. Alfabetização ecológica: o desafio para a educação do século 21. Coordenação André Trigueiro. Rio de Janeiro: Sextante, 2003.

COVRE, Maria de Lourdes Mazini. O que é cidadania. São Paulo: Editora Brasiliense, 1991.

DI PIETRO, Maria Sylvia Zanella. Direito administrativo. 15. ed. São Paulo: Atlas, 2003.

FELDMANN, Fábio. Consumismo. In: Meio ambiente no século 21: 21 especialistas falam da questão ambiental nas suas áreas de conhecimento. Coordenação André Trigueiro. Rio de Janeiro: Sextante, 2003. [p.143-157].

FIORILLO, Celso Antônio Pacheco. Curso de direito ambiental brasileiro. 8. ed. rev., atual. e ampl. São Paulo: Saraiva, 2007.

FREITAS, Vladimir Passos de. Direito administrativo e meio ambiente. 3. ed. Curitiba: Juruá, 2001.

LUZ, Gastão Octávio da. A formação de formadores em educação ambiental nos cenários da "Região Metropolitana de Curitiba". Da resistência dos fatos. Tese de Doutorado - UFPR. Curitiba/PR. 2001.

MILARÉ, Edis. Direito do ambiente. São Paulo: Revista dos Tribunais, 2001.

Direito do ambiente. 3. ed. rev. atual e ampl. São Paulo: Revista dos Tribunais, 2003.

NEVES, F. de F. R.; LEITE, I. D'Azevedo; BRAMBILLA, M. A.; ACCARDO, R. P. O exercício da educomunicação e da cidadania no jornalismo: o trabalho de Gilberto Dimenstein. Intercom - Sociedade Brasileira de Estudos Interdisciplinares da Comunicação XXX Congresso Brasileiro de Ciências da Comunicação - Santos - 29 de agosto a 2 de setembro de 2007. 
SANTOS, Antônio Silveira R. dos. Meio ambiente do trabalho: considerações. Jus Navigandi, Teresina, ano 4, n. 45 , set. 2000.

SILVA, José Afonso da. Direito ambiental constitucional. 5. ed. São Paulo: Malheiros, 2004.

TRIGUEIRO, André (Coordenação). Meio ambiente no século 21: 21 especialistas falam da questão ambiental nas suas áreas de conhecimento. Rio de Janeiro: Sextante, 2003. 